\title{
ALIGNING CORPORATE SOCIAL RESPONSIBILITY WITH GOVERNMENT SOCIAL MISSION IN CREATING SUSTAINABILITY DEVELOPMENT
}

\author{
Dianne Frisko \\ University of Surabaya \\ difrisko1@yahoo.fr \\ Desi Arisandi \\ University of Surabaya \\ desidelpiero@gmail.com
}

\begin{abstract}
Purposes:

The purpose of this paper is to analyze the practice of corporate social responsibility (CSR) ran by stateowned company in Indonesia which tend to focus on strengthening economies of small medium enterprise (SME) through partnership program as per regulation framework. Paper analysis included in examining the background of program, assess it impact to stakeholder, and evaluate the effectiveness of social program done by state-owned company so far. It characteristic as public service organization as well as profit-generating enterprise, drive companies to follow some regulations pertaining with social responsibility activities. Eventually, this paper expected to provide information about effectiveness analysis of CSR programs for company and government to design proper rules in creating sustainability development for a better future.
\end{abstract}

\section{Method:}

As a basic qualitative research, this study attempt to examine the practice of social responsibility program within state-owned company. Object to be analysis in this paper, focus on state-owned company in Indonesia. This analysis based on literature study, supported by secondary data published, and information gathered through public hearing within state-owned company, local parliament and government parties. In doing analysis phase, this paper represent data period of social responsibility program done and it emerged concept application within years 2007-2010 of CSR practice and its impact within state-owned company in Indonesia, and regulation designed by government. The explanatory research study in this paper, represent a study on state-owned company social activities in developing country, which challenges further study to explore more potential research area.

\section{Preliminary findings:}

Some study encounter that most CSR programs within state-owned company in Indonesia run in a mandatory framework, and found has been leaving potential power to enhance economic growth and attain sustainability development. The gap lies in government policy to encourage corporate entities to communicate and coordinate with stakeholder, to align company social responsibility with government social mission in creating sustainability development. 


\section{Potential contribution to the literature:}

Findings through this paper analysis, potentially contribute the information about the effectiveness of CSR practice in developing country, which done through mandatory framework. Through its deep and holistic analysis, this paper describe factors trigger corporate doing their social activities in developing country, its performance measures, its impact and its evaluation method which found differ with voluntary concept of CSR mostly success in developed country.

This paper also potentially contribute the information to be considered in law-economic studies, pertaining with the way enhancing business ethics within corporation, from legal aspect of CSR. This paper imply the role of government and parliament in designing regulation regarding with CSR activities to attain win-win solutions and sustainability development based on social responsibility conceptual framework.

Keywords: Corporate Social Responsibility, Sustainability Development, State-owned Company 